\title{
Interhemispheric subdural and subarachnoid haemorrhage in a patient with amphetamine-induced vasculitis
}

\author{
Eric Patrick Nagele, ${ }^{1}$ Anika Ross, ${ }^{2}$ Ryna Karina Then, ${ }^{1}$ Tapan Kavi ${ }^{3}$
}

'Department of Neurology, Cooper University Hospital, Camden, New Jersey, USA ${ }^{2}$ Edward Via College of Osteopathic Medicine, Blacksburg, Virginia, USA ${ }^{3}$ Department of Neurosurgery, Cooper University Hospital, Camden, New Jersey, USA

\section{Correspondence to} Dr Eric Patrick Nagele, nagele-eric@cooperhealth.edu

Accepted 28 November 2017

\section{DESCRIPTION}

A 27-year-old woman with a history of pulmonary embolism presented with confusion and depressed arousal after a night of alcohol and drug use. On examination, she was found to have lack of motivation and right leg weakness but had no other significant neurological findings. Trauma survey did not detect any signs of injury. CT scan of the head revealed interhemispheric subdural and subarachnoid haemorrhage with the highest volume in left frontoparietal region (figure 1). Urine toxicology showed presence of tetrahydrocannabinol and amphetamines. CT angiography demonstrated a small, incidental left supraclinoid internal carotid artery aneurysm but no other significant findings (figure 1). MRI was remarkable only for the haemorrhage and MR venogram confirmed patent venous sinuses (figure 1). Given the patient's history
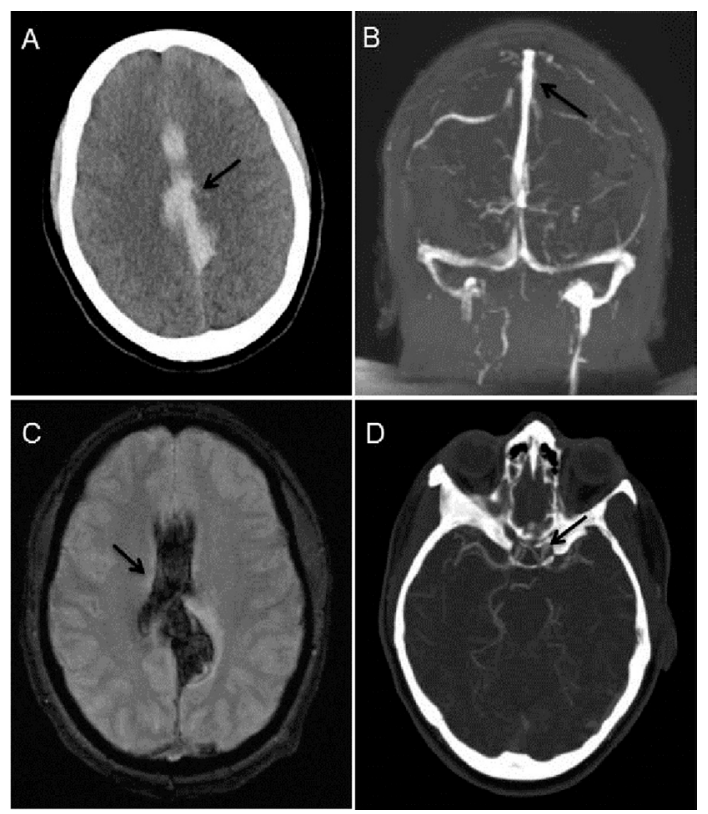

Figure 1 A) Non-contrast head CT revealing extensive interhemispheric and subarachnoid haemorrhage (arrow). (B) MRV of the Head demonstrating patency of the sagittal sinus in the region of the haemorrhage (arrow) and absence of dural sinus thromboses.

(C) MRI brain, hemoflash sequence, corroborating the area of haemorrhage (arrow). (D) CT angiogram of head demonstrating a small, incidental left supraclinoid internal carotid artery aneurysm (arrow). No obvious vasculitic changes or abnormalities in the areas of intracranial haemorrhage seen.

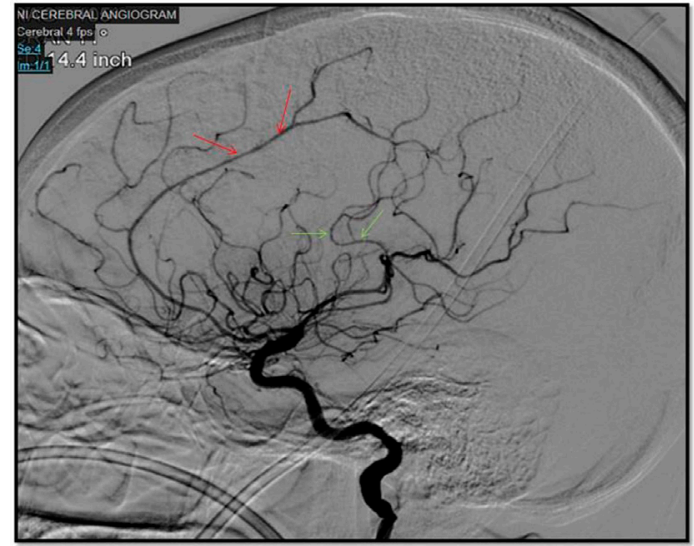

Figure 2 Sagittal view of cerebral angiogram showing areas of luminal irregularity and beading in left anterior cerebral artery (red arrows) and left middle cerebral artery (green arrows).

of drug use and the presence of amphetamines in her urine, conventional cerebral angiography was obtained to evaluate for vasculopathy. Cerebral angiogram revealed areas of luminal irregularity and beading, noted mainly in the middle cerebral and anterior cerebral arteries (figure 2). The patient was evaluated for primary and secondary causes of vasculitis via extensive clinical and laboratory investigation. No significant findings were present except for a mild elevation in erythrocyte sedimentation rate and $\mathrm{C}$ reactive protein. A lumbar puncture was performed and revealed normal cell and protein counts. Amphetamine-induced vasculitis was deemed the most likely diagnosis, and the patient was treated supportively. Over the course of hospital stay, she had mild improvement in abulia and right-sided weakness and was eventually discharged to rehabilitation.

\section{Learning points}

- Amphetamine use is an uncommon, but well-established precipitant of cerebral vasculitis, also known as reversible cerebral vasoconstriction syndrome.

- Amphetamine-induced vasculitis should be considered in the differential diagnosis for non-traumatic subdural or subarachnoid haemorrhage, especially in patients with history of drug use. 
Amphetamine use has been well recognised as a rare precipitant of cerebral vasculitis and intracerebral haemorrhage. ${ }^{1}$ Amphetamine induced vasculitis, also known as reversible cerebral vasoconstriction syndrome, is commonly associated with convexity subarachnoid haemorrhage, focal intracerebral haemorrhage, cerebral infarction, and reversible cerebral oedema. ${ }^{2}$ The exact pathogenesis is unknown, but it has been identified in both first-time and long-standing users of amphetamines and is suspected to be related to vascular changes induced by sudden and drastic catecholamine release. ${ }^{3}$ The unique aspect of this case is presence and degree of interhemispheric subdural and subarachnoid haemorrhage without head trauma, which has not been previously reported with amphetamine vasculitis to our knowledge.

In summary, amphetamine-induced vasculitis should be considered in the differential diagnosis for non-traumatic interhemispheric subdural or subarachnoid haemorrhage, especially in patients with a history of drug use.
Contributors EPN, RKT and TK contributed to the conceptualisation, drafting and finalisation of the submitted work. AR contributed to the conceptualisation and drafting of the submitted work.

Competing interests None declared.

Patient consent Obtained.

Provenance and peer review Not commissioned; externally peer reviewed.

(C) BMJ Publishing Group Ltd (unless otherwise stated in the text of the article) 2017. All rights reserved. No commercial use is permitted unless otherwise expressly granted.

\section{REFERENCES}

1 Ducros A. Reversible cerebral vasoconstriction syndrome. Lancet Neurol 2012:11:906-17.

2 Abdel Razek AA, Alvarez H, Bagg S, et al. Imaging spectrum of CNS vasculitis. Radiographics 2014:34:873-94.

3 Buxton N, McConachie NS. Amphetamine abuse and intracranial haemorrhage. J $R$ Soc Med 2000:93:472-7.

Copyright 2017 BMJ Publishing Group. All rights reserved. For permission to reuse any of this content visit

http://group.bmj.com/group/rights-licensing/permissions.

BMJ Case Report Fellows may re-use this article for personal use and teaching without any further permission.

Become a Fellow of BMJ Case Reports today and you can:

- Submit as many cases as you like

- Enjoy fast sympathetic peer review and rapid publication of accepted articles

- Access all the published articles

- Re-use any of the published material for personal use and teaching without further permission

For information on Institutional Fellowships contact consortiasales@bmjgroup.com

Visit casereports.bmj.com for more articles like this and to become a Fellow 